\title{
Revision and morphological analysis of the Ragadidae (Insecta, Diptera)
}

\author{
Emma WAHLBERG \\ Department of Zoology, Swedish Museum of Natural History, P. O. Box 50007, SE-104 05 Stockholm, \\ Sweden and Department of Zoology, Stockholm University, S-106 91 Stockholm, Sweden. \\ Email: emma.wahlberg@nrm.se \\ urn:lsid:zoobank.org:author:CB7636CE-FC44-403A-BAFD-C9F7C22A57CE
}

\begin{abstract}
Several taxonomic groups within Empidoidea Latreille, 1809 have been subject to unclear phylogenetic assignments along with multiple parallel hypotheses causing difficulties in classification and morphological identification. This study reviews the internal classification of the Ragadidae and includes a diagnosis and description of all included subfamilies and genera based on the results of an analysis of morphological characters using maximum parsimony. Illustration of important characters and a key to all genera in the family is given. The genus Hormopeza Zetterstedt, 1838 is found to be most closely related to Anthepiscopus Becker, 1891 and Iteaphila Zetterstedt, 1838, and the subfamily Iteaphilinae Wahlberg \& Johanson, 2018 is therefore expanded to also include that genus. Hormopeza is consequently excluded from Ragadinae Sinclair, 2016. This study provides diagnoses, descriptions and keys in a contribution to a thorough classification of the empidoid groups and increased ease in morphological recognition.
\end{abstract}

Keywords. Diptera, Empidoidea, Ragadidae, revision, taxonomy.

Wahlberg E. 2019. Revision and morphological analysis of the Ragadidae (Insecta, Diptera). European Journal of Taxonomy 521: 1-19. https://doi.org/10.5852/ejt.2019.521

\section{Introduction}

Chvàla (1976) erected the subfamily Oreogetoninae Chvàla, 1976 and included the genera Anthepiscopus Becker, 1891, Hormopeza Zetterstedt, 1838, Gloma Meigen, 1822, Iteaphila Zetterstedt, 1838, Oreogeton Schiner, 1860 and Ragas Walker, 1837. This subfamily was hypothesized to be the sister group to the remaining subfamilies (Chvàla 1976, 1983) in Empididae Latreille, 1809. More than twenty years later, Sinclair (1999) proposed the erection of the 'Ragas-group' within the Empididae, and included the genera Dipsomyia Bezzi, 1909, Hormopeza, Hydropeza Sinclair, 1999, Ragas and Zanclotus Wilder, 1982. The monophyly of this group was supported by Sinclair \& Cumming (2006) based on morphological analyses, and Sinclair (2016) later raised it to the rank of subfamily as Ragadinae Sinclair, 2016. The genus Iteaphila, earlier proposed by Chvàla to be related to Ragas, was proposed by Sinclair \& Cumming (2006) to be distantly related and they stated that Iteaphila together with Anthepiscopus are incertae sedis within the Empidoidea. The authors also left Oreogeton unplaced within the Empidoidea. The 
genus Gloma was transferred to the Trichopezinae Sinclair, 1995 (Brachystomatidae Melander, 1908 sensu Sinclair \& Cumming, 2006) by Sinclair (1995).

In a recent analysis (Wahlberg \& Johanson 2018), the Ragadinae and the 'Iteaphila-group' were brought together within the family Ragadidae, and the 'Iteaphila-group' was included in the newly erected subfamily Iteaphilinae Wahlberg \& Johanson, 2018. Supported by DNA sequence data, the Ragadidae were hypothesized to form the sister group to the Empididae. This recent change in taxonomic status and generic composition, however, left internal relationships unresolved. The objectives of this paper are to provide the results from an analysis of the internal relationships within the family, updated diagnostic characters to reflect the new classification, and determination keys to the included genera applicable to both males and females.

\section{Material and methods}

This study comprises all genera included in the Ragadidae and is based on material borrowed from the institutions listed under each taxon in the results. Each genus is represented by the type species, in most cases also the type material. For photographic purposes and detailed studies, non-types were applied to reduce the damage risk. Photographic equipment for dry material was a Nikon DS-Ri2 mounted on a motorized Nikon SMZ microscope. Automatic focus stacking was performed in Nikon NIS-Elements 5.10 connected to the camera. Dissected material was mounted in Euparal or glycerol and photographed using a Nikon D7100 mounted on a Leitz Orthoplan large field microscope, with manual focusing and subsequent stacking in Helicon Focus 6.8.0. Photos were edited and finalized in Adobe Photoshop CC 20.0.1. Pencil drawings were edited in Adobe Illustrator CC 23.0.1. A phylogenetic analysis based on 28 morphological characters, applied by Sinclair $(1999,2016)$, Sinclair \& Cumming (2006) and Wahlberg \& Johanson (2018) with the addition of new characters (Table 1), was executed in PAUP* ver. 4.0a164 (Swofford 2003). The most parsimonious trees were found using the heuristic search option with random stepwise addition with 1000 replicates and TBR branch swapping, MulTrees enabled, and 1000 bootstrap replications. All characters were unordered and unweighted, and the character matrix is presented in Table 2. The species of the Dolichopodidae Latreille, 1809 Dolichopus ungulatus Linnaeus, 1758, and two species of the Empididae, Trichopeza longicornis Meigen, 1822 and Clinocera nigra Meigen, 1804, were selected as outgroups to root the character transformations. Characters were mapped and visualized on the resulting tree in MacClade 4 (Maddison \& Maddison 2001), and the tree was annotated in Adobe Illustrator CC 23.0.1. The terminology applied for morphological details follows Cumming et al. (1995) for the male terminalia, McAlpine (1981) for the morphology of adult and wing, and Stuckenberg (1999) for the antennae. In the case of the second anterior branch of the cubitus in the wing (traditionally referred to as $\mathrm{CuA} 2$ ), the more recent interpretation is followed (Cumming \& Wood 2017). In this case the $\mathrm{CuA} 2$ is now referred to as $\mathrm{CuA}$. The dorsal and ventral projections of the epandrium is interpreted as dorsal and ventral surstyli, respectively.

\section{Abbreviations of morphological characters}

$\begin{array}{lll}\mathrm{CuA} & = & \text { anterior branch of cubital vein cubitus plus anal veins } \\ \mathrm{R}_{\mathrm{S}} & = & \text { radial sector } \\ \mathrm{R}_{1} & = & \text { anterior (first) branch of the radial vein } \\ \mathrm{R}_{4+5} & = & \text { branch } 4 \text { plus } 5 \text { of the radial vein } \\ \mathrm{h} & = & \text { humeral crossvein }\end{array}$


Table 1. Characters used in the analysis.

\begin{tabular}{|c|c|c|}
\hline$\#$ & Character & State alternatives \\
\hline 1. & Male eyes type & 1. holoptic; 2. dichoptic. \\
\hline 2. & Eye setation & 1. bare; 2. pubescent. \\
\hline 3. & Scape setation & 1. with setae; 2 . bare. \\
\hline 4. & Shape of postpedicel & 1. tapering; 2 . ovate and broad. \\
\hline 5. & Length of postpedicel & 1. at most 2.5 times as broad; 2 . at least 3 times as wide. \\
\hline 6. & Shape of stylus & 1. tapering; 2 . cylindrical. \\
\hline 7. & Shape of labrum & 1. straight; 2 . recurved. \\
\hline 8. & Labrum apex shape & 1. pointed; 2. truncate. \\
\hline 9. & Epipharyngal blades & 1. present; 2 . absent. \\
\hline 10. & Ventroapical comb on labrum & 1. present; 2 . absent. \\
\hline 11. & Postgenal setae & 1. with stout spine like setae; 2 . bare or with setae, not spine like. \\
\hline 12. & Prosternum and proepisternum & $\begin{array}{l}\text { 1. prosternum fused with proepisternum; } 2 \text {. prosternum separated } \\
\text { from proepisternum. }\end{array}$ \\
\hline 13. & Laterotergite setation & 1. with setae; 2 . bare. \\
\hline 14. & $\begin{array}{l}\text { Setation on anterior face of fore } \\
\text { coxa }\end{array}$ & $\begin{array}{l}\text { 1. with at most slender and fine setae; } 2 \text {. with stout, spine like } \\
\text { setae. }\end{array}$ \\
\hline 15. & $\begin{array}{l}\text { Inner ventral margin of fore } \\
\text { trochanter }\end{array}$ & 1. with spine like setae; 2 . with trichoid setae. \\
\hline 16. & Tubercle on fore coxa & 1. present; 2. absent. \\
\hline 17. & Male fore tarsal claws & 1. present; 2 . absent. \\
\hline 18. & Costal bristle & 1. present; 2 . absent. \\
\hline 19. & Subcosta shape & $\begin{array}{l}\text { 1. reaching, of fading just before, costa; } 2 \text {. abruptly ending before } \\
\text { costa; 3. curved towards } \mathrm{R}_{1} \text {. }\end{array}$ \\
\hline 20. & Shape of Vein $R_{4+5}$ & 1. branched; 2. unbranched. \\
\hline 21. & Shape of $\mathrm{CuA}$ & 1. recurved; 2. truncate. \\
\hline 22. & Female: tergite 10 & $\begin{array}{l}\text { 1. divided medially; } 2 \text {. undivided; } 3 \text {. divided and fused to cercus; } \\
\text { 4. absent. }\end{array}$ \\
\hline 23. & Male: tergite 8 shape & 1. slender; 2. broad; 3. absent. \\
\hline 24. & Male: postgonites & $\begin{array}{l}\text { 1. fused processes from hypandrium; } 2 \text {. articulated to } \\
\text { hypandrium. }\end{array}$ \\
\hline 25. & Male: presence of ventral surstylus & 1. absent; 2. present. \\
\hline 26. & Male: ventral surstylus position & 1. absent; 2. apical; 3. subapical, on inner margin of epandrium. \\
\hline 27. & Male: cercus sclerotization & 1. thinly sclerotized; 2 . heavily sclerotized. \\
\hline 28. & Male: apex of phallus & 1. simple; 2 . with membranous tube. \\
\hline
\end{tabular}

\section{Institutional abbreviations}

The following depository institutions are mentioned in the text below, following Evenhuis (2019).

MTD $=$ Museum für Tierkunde, Dresden, Germany

NHRS $=$ Naturhistoriska riksmuseet, Stockholm, Sweden

NHMW $=$ Naturhistorisches Museum Wien, Vienna, Austria

MZLU $=$ Lund University, Lund, Sweden

NZAC $=$ New Zealand Arthropod Collection, Landcare Research, Auckland, New Zealand

USNM = National Museum of Natural History, Smithsonian Institution, Washington DC., USA 
Table 2. Matrix of scored morphological characters used in analysis.

\begin{tabular}{llll}
\hline \multicolumn{1}{c}{ Character } & & 1111111111 & 222222222 \\
Taxa & 123456789 & 0123456789 & 012345678 \\
\hline Dolichopus ungulata (Linnaeus, 1758) & 121211111 & 2211122113 & 211322211 \\
\hline Trichopeza longicornis Meigen, 1822 & 121121111 & 2212122112 & 111112221 \\
Clinocera nigra Meigen, 1804 & 221111111 & 2211122111 & 111112221 \\
\hline Anthepiscopus oedalinus (Zetterstedt, 1838) & 111122122 & 2222122121 & 21321111 \\
\hline Iteaphila macquarti Zetterstedt, 1838 & 111122122 & 2222122121 & 113211111 \\
\hline Dipsomyia spinifera Bezzi, 1909 & 211111221 & 1221222111 & 121112212 \\
Hormopeza obliterata Zetterstedt, 1838 & 112212221 & 1222122211 & 122211112 \\
\hline Hydropeza longipennae (Miller, 1923) & 221111221 & 2212222112 & 112112212 \\
Ragas unica Walker, 1837 & 112112221 & 1122212121 & 122122312 \\
\hline Zanclotus dioktes Wilder, 1982 & 221111221 & 1122211121 & 114122212 \\
\hline
\end{tabular}

\section{Results}

\section{Phylogeny}

The strict consensus tree based on a total of 14 trees (Fig. 1) from the maximum parsimony analysis (tree length $=54$, consistency index $=0.611$, retention index $=0.632$, and rescaled consistency index $=0.386$ ) showed that the Ragadidae form a monophyletic unit in relation to the outgroup taxa. Anthepiscopus and Iteaphila together form a monophyletic sister group to Hormopeza. The close relationship between Hormopeza and the Iteaphilinae is supported by unique characters in the male terminalia; tergite 8 is broad and rectangular (character 23:2) and has lost the differentiated ventral surstylus (character 25:1). The phylogenetic relationships between the remaining genera are presently unresolved.

\section{Taxonomy}

Order Diptera Linnaeus, 1758

Superfamily Empidoidea Latreille, 1809

Family Ragadidae Sinclair, 2016

Figs $2 \mathrm{~A}-\mathrm{C}, 3,4 \mathrm{~A}-\mathrm{C}, 5$

\section{Diagnosis}

The Ragadidae are separated from the Dolichopodidae and the Hybotidae Meigen, 1820 by the presence of unrotated and symmetrical male genitalia, and with a point of origin of $\mathrm{R}_{\mathrm{S}}$ at a distance from crossvein $\mathrm{h}$ being equal to, or longer than, crossvein $\mathrm{h}$. The family is distinguished from the Atelestidae Hennig, 1970 in having a circumambient costa. It is separated from the Empididae by a prosternum that is separated from the proepisternum (except in species of Hydropeza). The representatives of Hydropeza are distinguished by the presence of a recurved labrum, which is straight in the Empididae.

\section{Description}

Labrum truncate apically. $\mathrm{R}_{\mathrm{S}}$ origins at a distance from crossvein $\mathrm{h}$ as long as or longer than crossvein $\mathrm{h}$ itself; subcosta reaches costa (except in Hydropeza spp.); $\mathrm{R}_{4+5}$ branched (except in Anthepiscopus spp.); costa circumambient. Prosternum separated from proepisternum (except in Hydropeza spp.); 
laterotergite bare (except in Dipsomyia spp.). Males: terminalia symmetrical and unrotated; postgonites present; cercus weakly sclerotized.

\section{Comments}

The diagnostic characters showed below are based on the results of Wahlberg \& Johanson (2018), reflecting the expanded concept of including the Iteaphilinae in the family. The Ragadidae are recorded from all the biogeographic regions except Antarctica, and fossil records in Baltic amber suggest this group to be at least 40 million years old (Sinclair 1999).

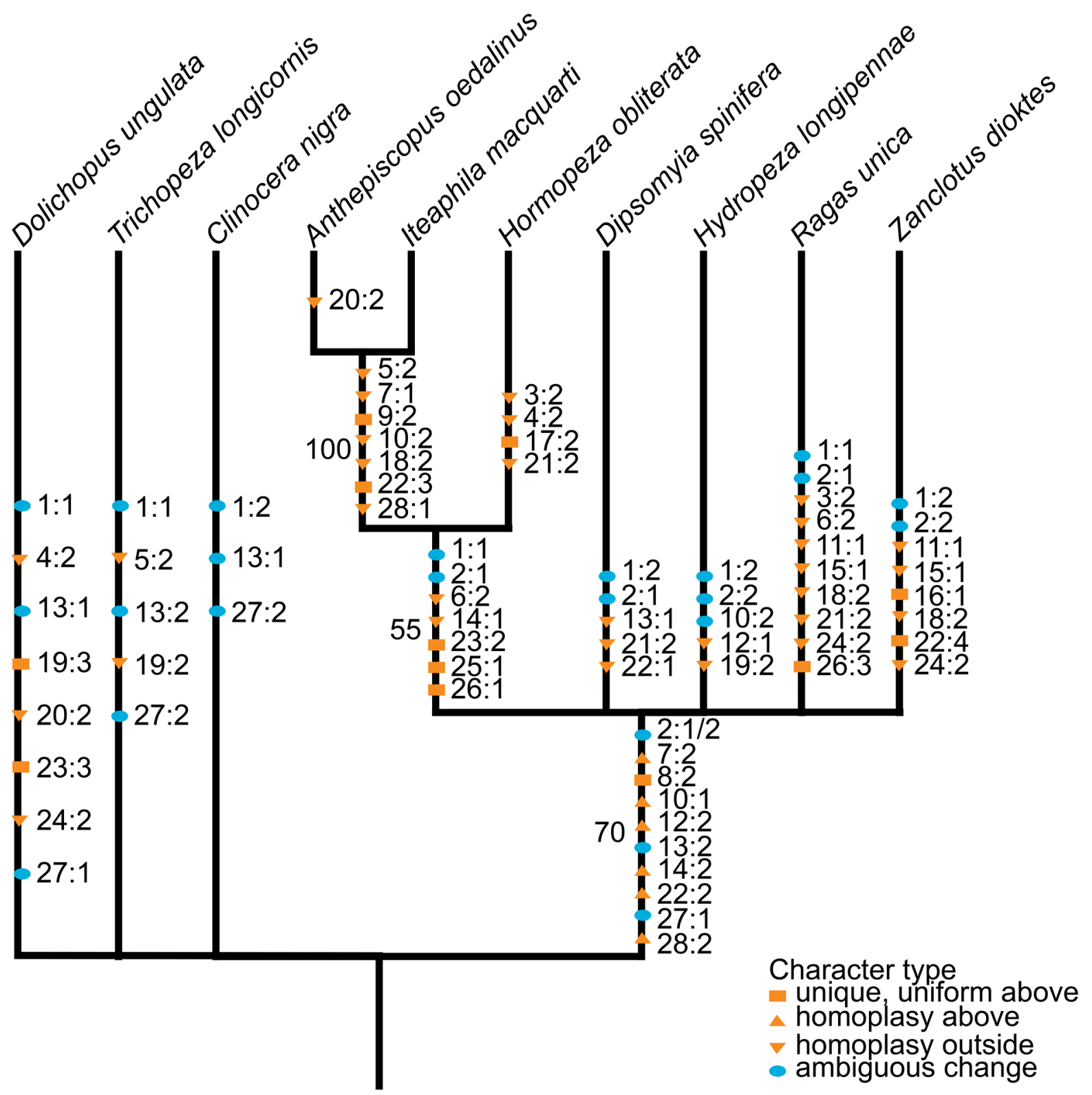

Fig. 1. The strict consensus tree from maximum parsimony analysis with characters mapped. Numbers to the right of character symbols and character numbers show bootstrap support values. 


\section{Included subfamilies}

Subfamily Ragadinae Sinclair, 2016.

Subfamily Iteaphilinae Wahlberg \& Johanson, 2018.

\section{Key to the subfamilies and genera}

1. Fore coxa with stout spine like setae on anterior face (Fig. 6A) .(Ragadinae) 2

- Stout spine like setae on anterior face of fore coxa absent (Fig. 6C) (Iteaphilinae) 5
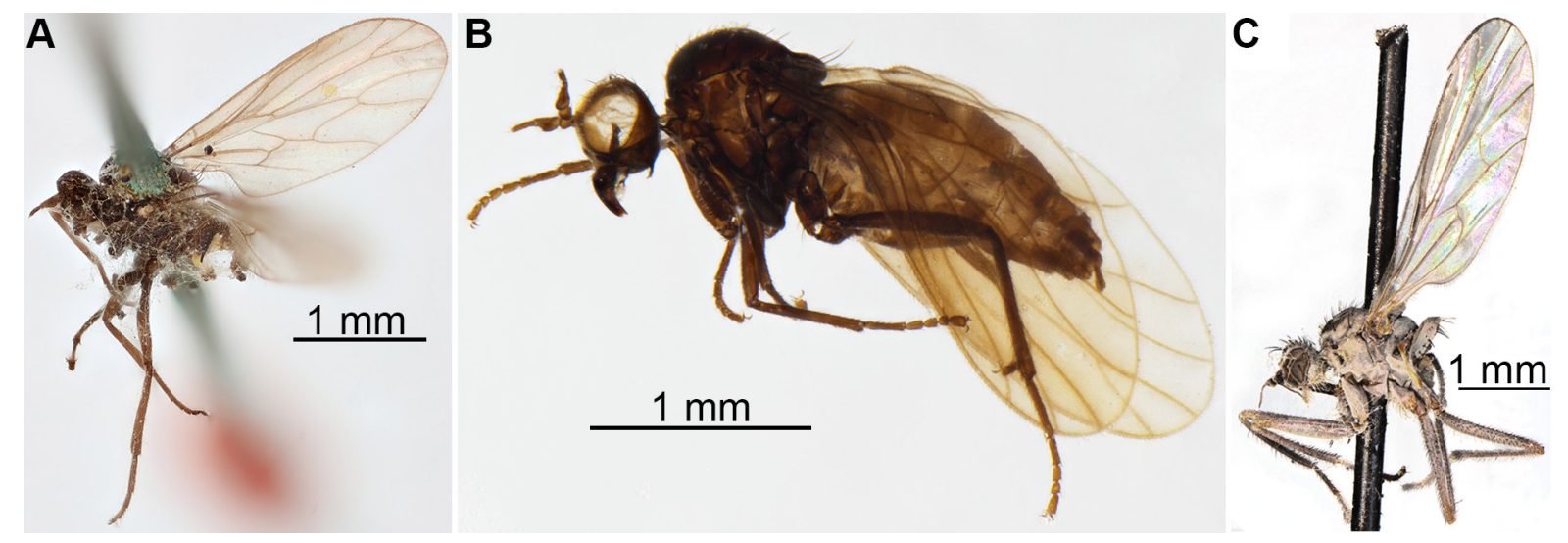

Fig. 2. Habitus, lateral view. A. Ragas unica Walker, 1837, $q$, lectotype (UZIL 2629:1; photo courtesy of Rune Bygebjerg, UZIL). B. Ragas unica, 1 q (NHRS). C. Dipsomyia spinifera Bezzi, 1909, +, holotype (MTD).

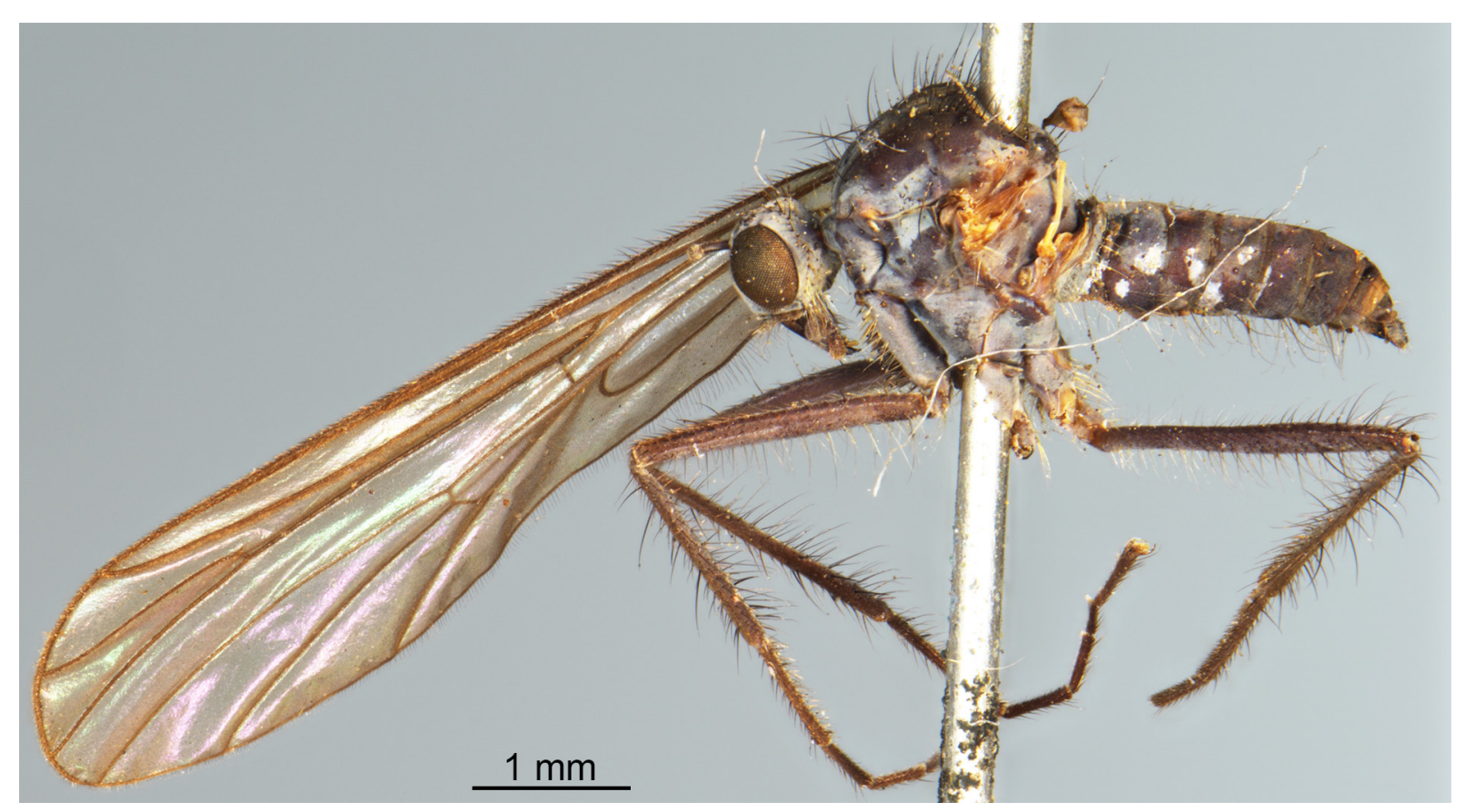

Fig. 3. Hydropeza longipennae (Miller, 1923),, , holotype, habitus, lateral view (NZAC 04021412). 

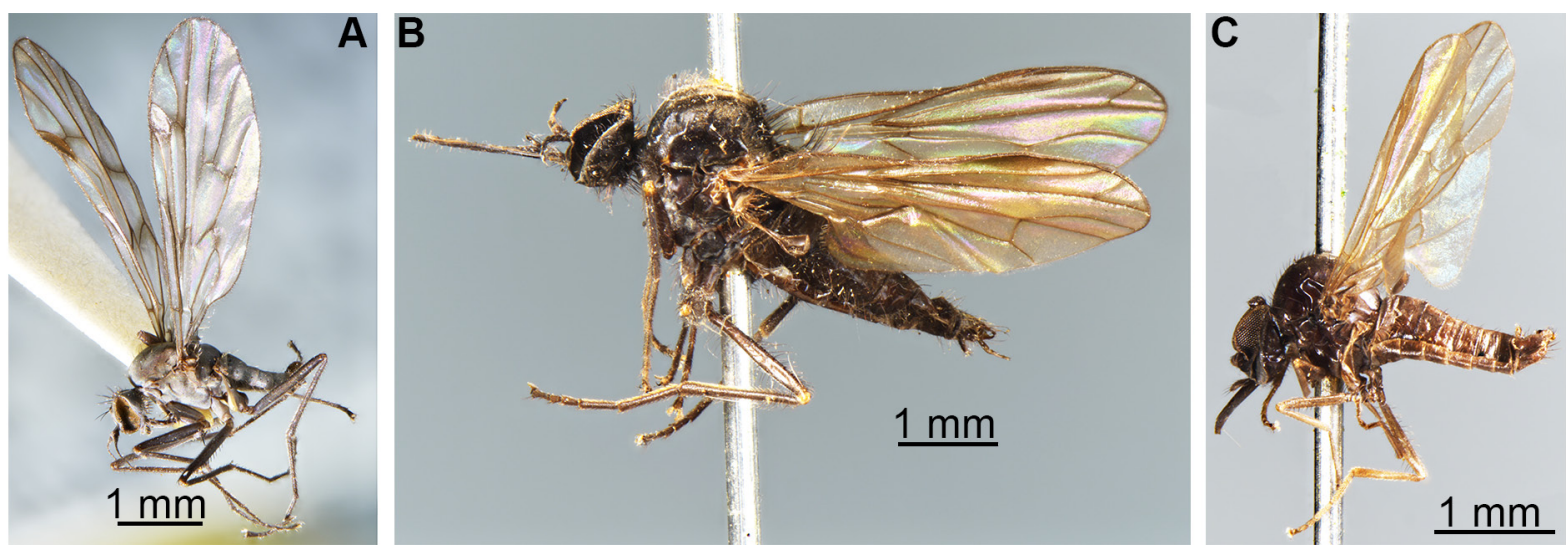

Fig. 4. Habitus, lateral view. A. Zanclotus dioktes Wilder, 1982, ô, holotype (USNM). B. Iteaphila macquarti Zetterstedt, 1838, q, holotype (MZLU 3028:1). C. Anthepiscopus oedalinus (Zetterstedt, 1838), ڤ̊ (NHRS-GULI000058764).

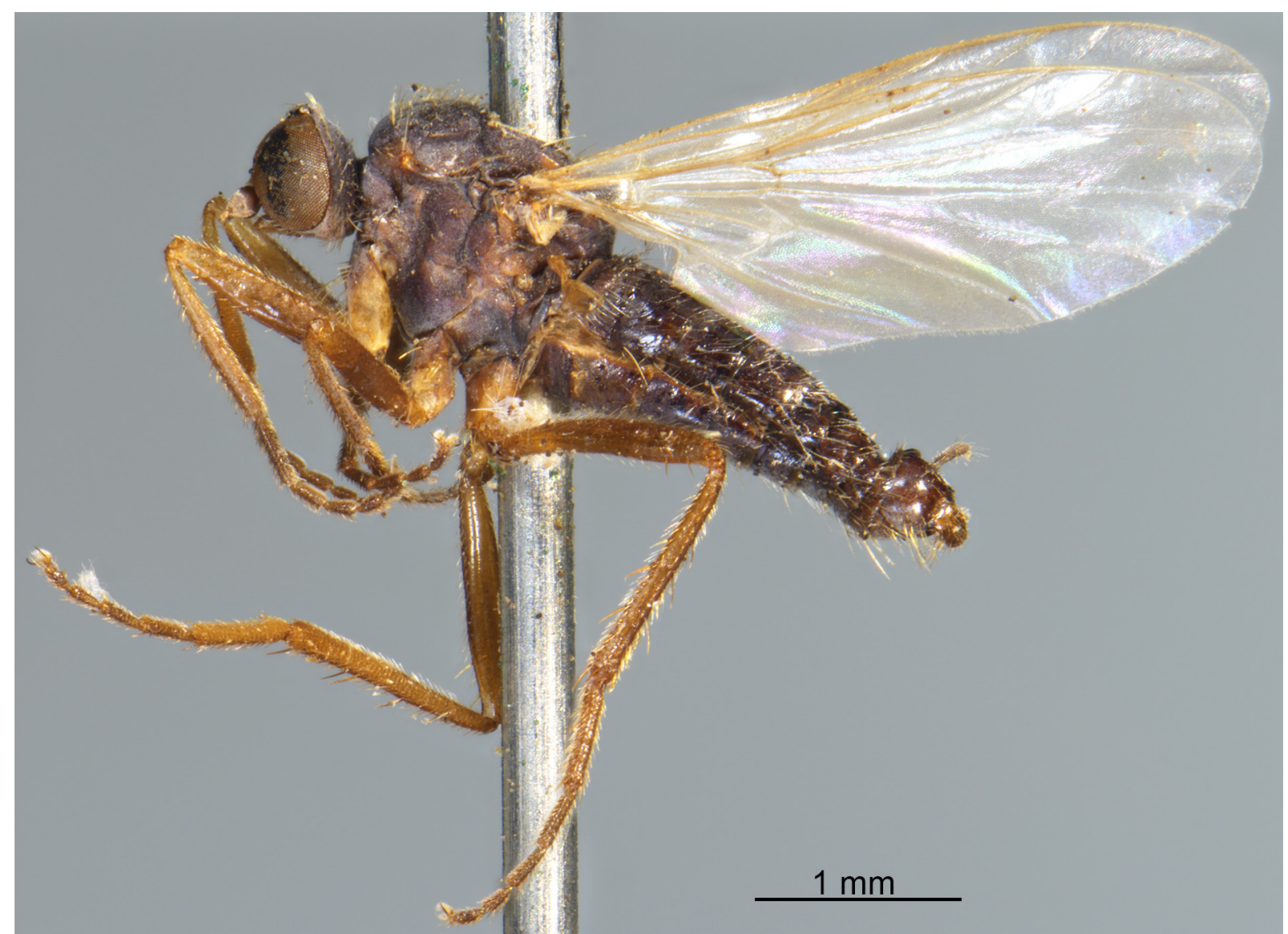

Fig. 5. Hormopeza obliterata Zetterstedt, 1838, ð̂, holotype, habitus, lateral view (MZLU 5863:1). 

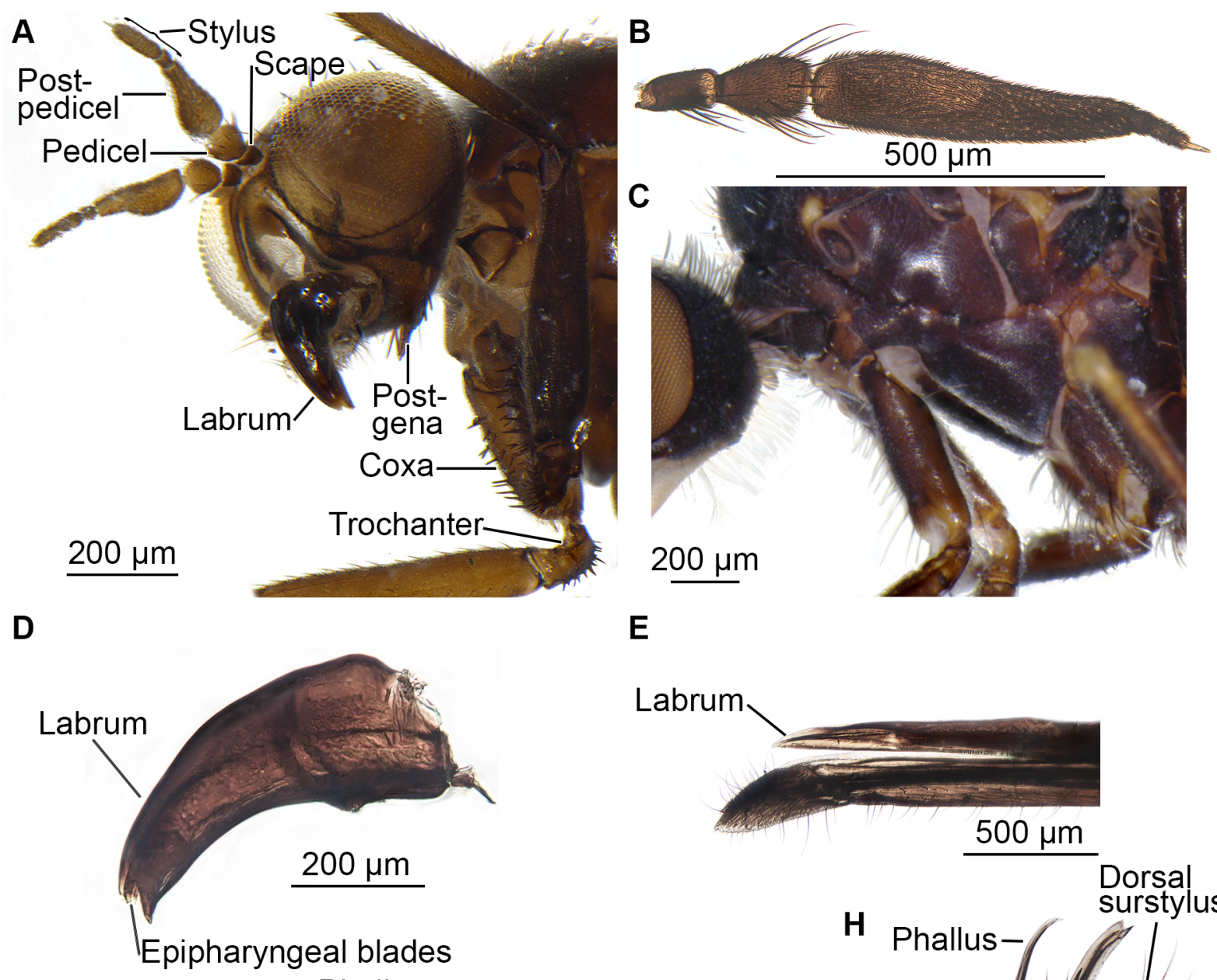

E
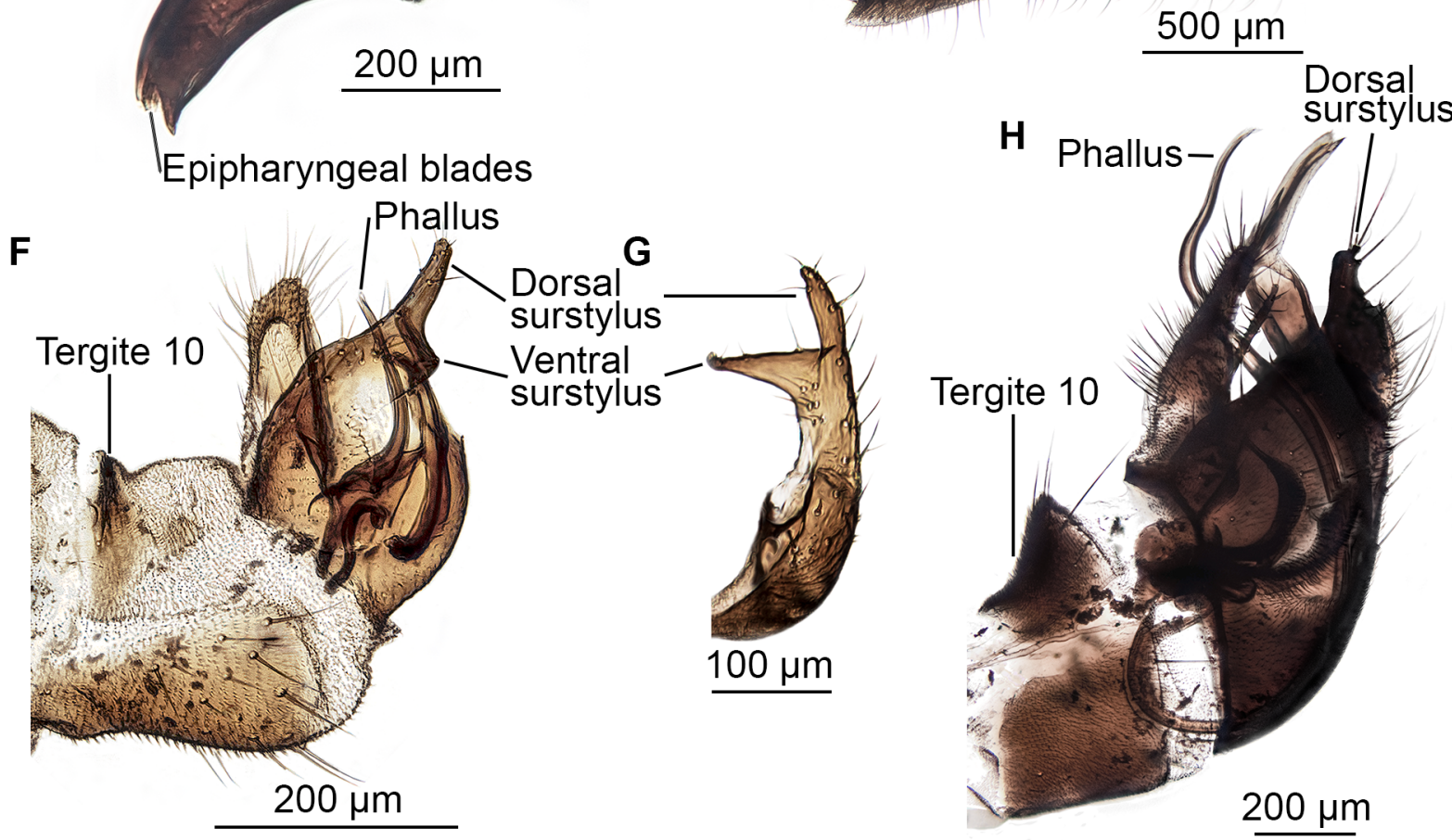

Fig. 6. Habitus, lateral view. A. Ragas unica Walker, 1837, head and fore leg (NHRS). B. Iteaphila macquarti Zetterstedt, 1838, antenna (NHRS). C. Iteaphila macquarti, head and fore leg (NHRS). D. Ragas unica, mouthparts (NHRS). E. Iteaphila macquarti, mouthparts (NHRS). F. Ragas unica, 1 ô, genitalia, lateral (NHRS). G. Ragas unica, 1 $\hat{\sigma}$, right epandrial lobe, dorsal (NHRS). H. Iteaphila

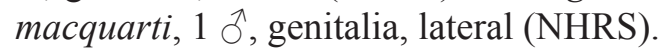


2. Postgena with stout spine like setae (Fig. 6A, 7C); wings without costal bristle; spine like setae present on inner ventral margin of fore trochanter (Figs 6A, 7G) .............................

- Postgena bare or with setae, not spine like (Figs 6C, 7A-B); costal bristle present; fore trochanter without spine like setae on inner margin (Figs 6C, 7F)

3. Eyes pubescent (Fig. 7C); in wings, CuA recurved (Fig. 9D); fore coxa with tubercle (Fig. 7G) Zanclotus Wilder, 1982

- Eyes bare (Fig. 6A); in wings, CuA straight (Fig. 9A); fore coxa without tubercle (Fig. 6A, cf. 7D-F)

Ragas Walker, 1837

4. Eyes pubescent (Fig. 7B); prosternum fused with proepisternum forming a precoxal bridge (Fig. 7E); laterotergite without setae Hydropeza Sinclair, 1999

- Eyes bare (Fig. 7A); prosternum separated from proepisternum forming an isolated sclerite (Fig. 7D); laterotergite with setae

Dipsomyia Bezzi, 1909

5. In wings, costal bristle present; CuA straight (Fig. 9G); scape always bare (Fig. 8A)

.. Hormopeza Zetterstedt, 1838

- In wings, costal bristle absent; CuA recurved (Figs 9E-F); scape always with setae (Fig. 6B) ...6

6. In wings, $\mathrm{R}_{4+5}$ branched into $\mathrm{R}_{4}$ and $\mathrm{R}_{5}$ (Fig. 9E) ........................ Iteaphila Zetterstedt, 1838

- In wings, $\mathrm{R}_{4+5}$ unbranched(Fig. 9F). Anthepiscopus Becker, 1891
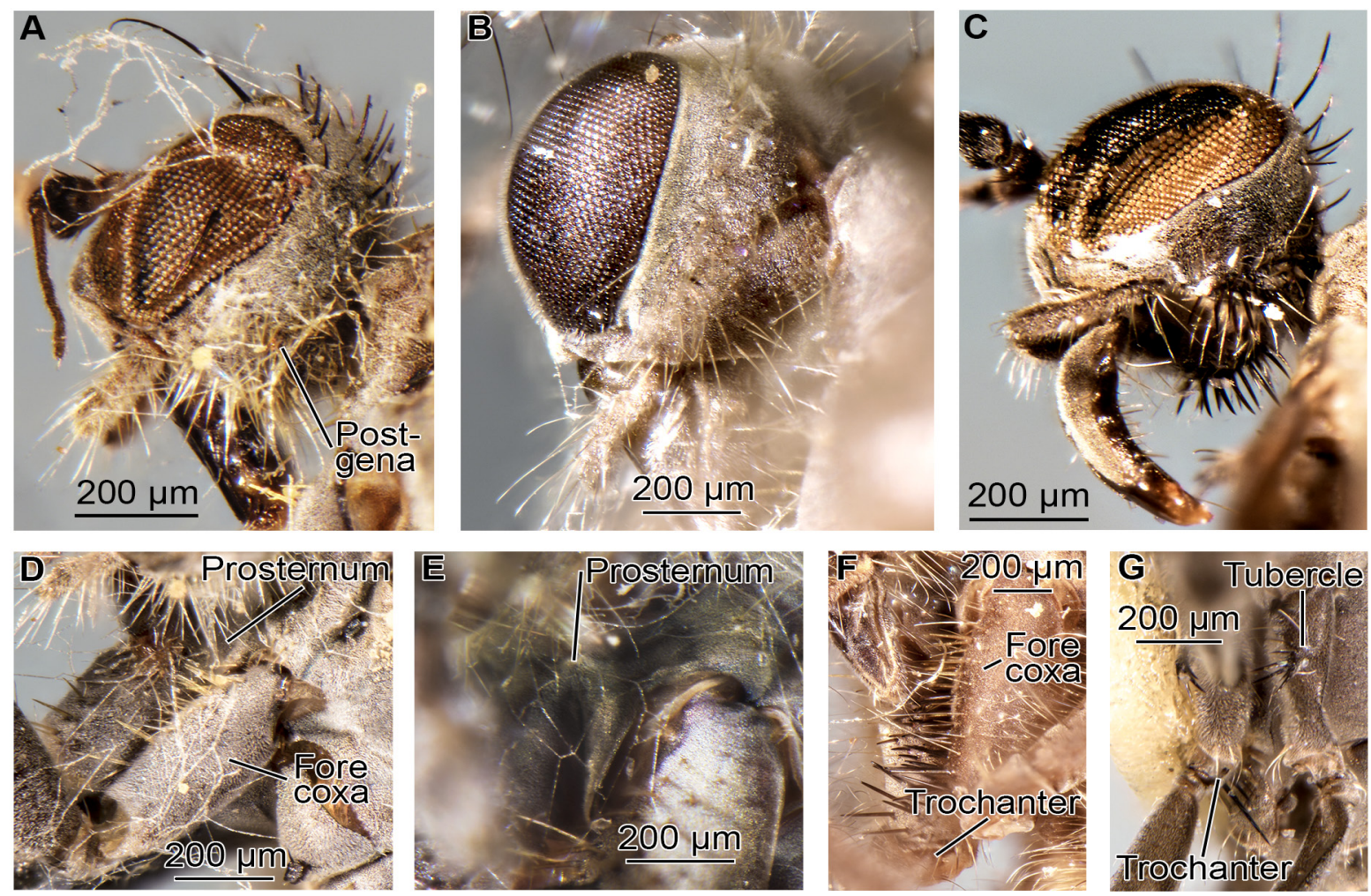

Fig. 7. A-C. Eye and postgena. A. Dipsomyia spinifera Bezzi, 1909 (MTD). B. Hydropeza longipennae (Miller, 1923) (NZAC 04021412). C. Zanclotus dioktes Wilder, 1982 (USNM). D. Dipsomyia spinifera, prosternum and fore coxa (MTD). E. Hydropeza longipennae, prosternum (NZAC 04021412). F-G. Fore coxa and trochanter. F. Hydropeza longipennae (NZAC 04021412). G. Zanclotus dioktes (USNM). 
Subfamily Ragadinae Sinclair, 2016

Figs $2 \mathrm{~A}-\mathrm{C}, 3,4 \mathrm{~A}, 9 \mathrm{~A}-\mathrm{D}$

\section{Diagnosis}

The species of the subfamily Ragadidae are distinguished from those of the Iteaphilinae by the length of the postpedicel and the shape of tergite 8 in males (see the description below and the key above for details). The stout and spine-like setae on fore coxa are synapomorphies for this group. Its included species can be further distinguished by the presence of a recurved labrum in both males and females (in the Iteaphilinae, the labrum is recurved only in the females of Hormopeza).

\section{Type genus}

Ragas Walker, 1837.

\section{Description}

Postpedicel always at most two and a half times as long as broad (Fig. 6A). Labrum recurved in both males and females (Fig. 6D). Anterior of fore coxa with stout, spine like setae (Fig. 6A). Males: tergite 8 slender in shape (Fig. 6F); ventral surstylus distinguishable (Fig. 6G).

\section{Comments}

The first formal description of this group included the genera Dipsomyia, Hormopeza, Hydropeza, Ragas, and Zanclotus (Sinclair 2016). In the analysis herein, it is found that this subfamily, excluding Hormopeza, can be distinguished only by a few diagnostic characters.

\section{Included genera}

Ragas Walker, 1837.

Dipsomyia Bezzi, 1909.

Hydropeza Sinclair, 1999.

Zanclotus Wilder, 1982.
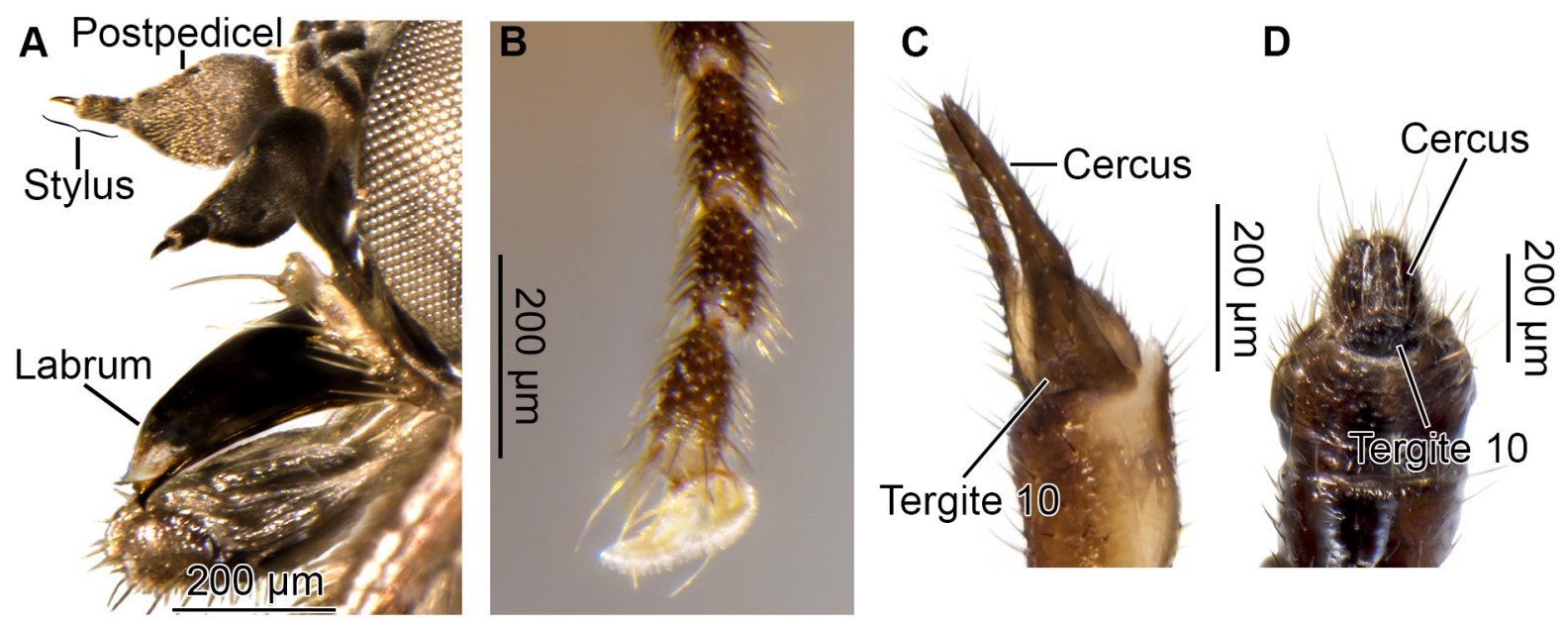

Fig. 8. A-B. Hormopeza obliterata Zetterstedt, 1838. A. Antennae and mouthparts, q (NHRS000061621). B. Apical part of tarsus, $\widehat{\partial}$ (NHRS-000061670). C-D. Terminalia,, . . C. Iteaphila macquarti Zetterstedt, 1838, dorsolateral (NHRS). D. Hormopeza obliterata, dorsal (NHRS-000061621). 
Genus Ragas Walker, 1837

Figs 2A-B, 6A, D, F-G, 9A

\section{Diagnosis}

The species in the genus Ragas are recognized by having spine like setae on the postgena and on the inner ventral margin of the fore trochanter, and lack costal bristles. These character stages are shared with species in the genus Zanclotus, from which they can be distinguished by having bare instead of pubescent eyes, and straight instead of recurved $\mathrm{CuA}$.

\section{Type species}

Ragas unica Walker, 1837.
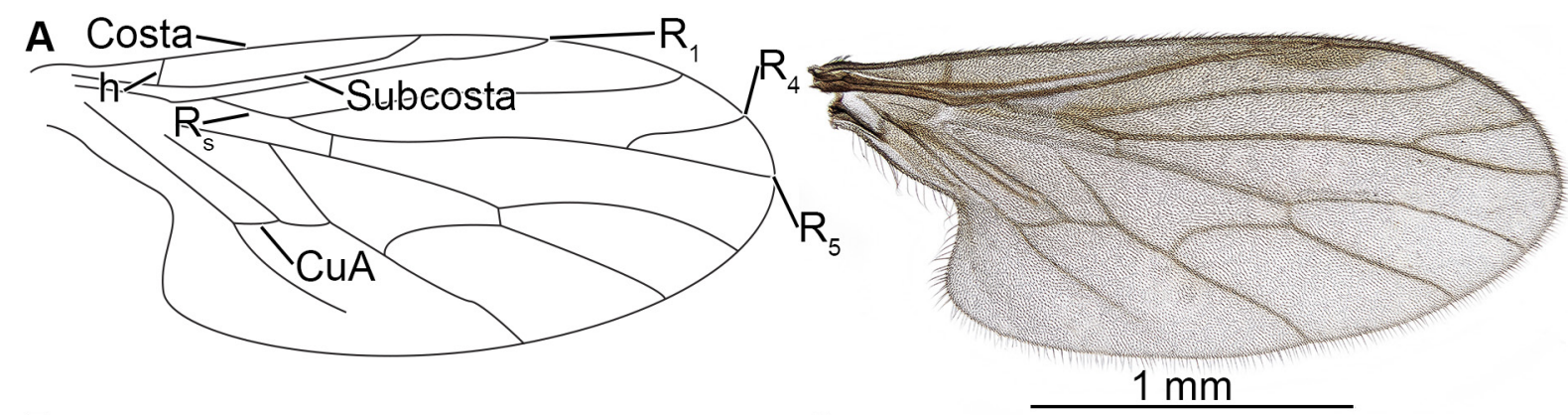

B

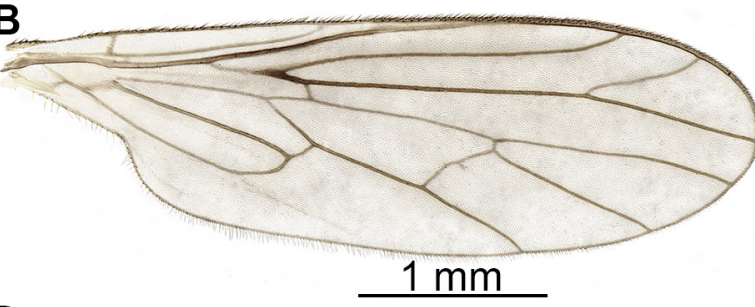

D

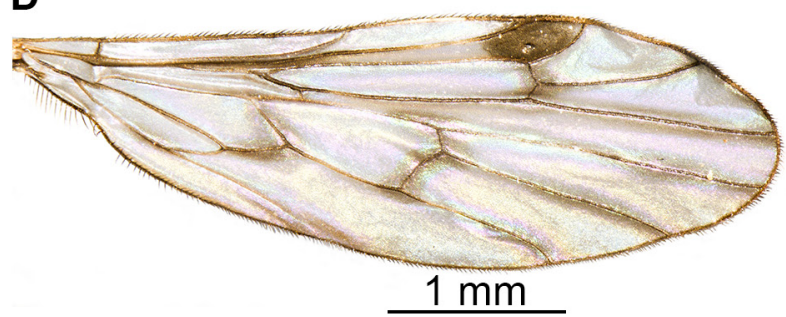

F

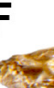

C

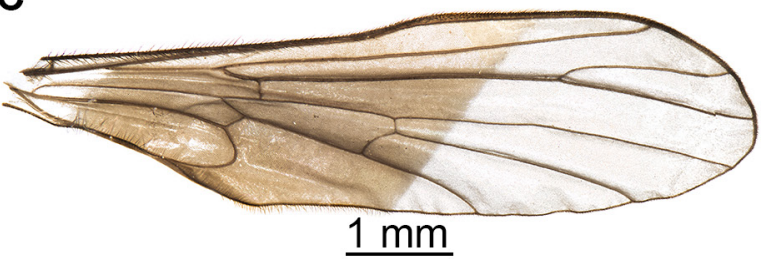

E

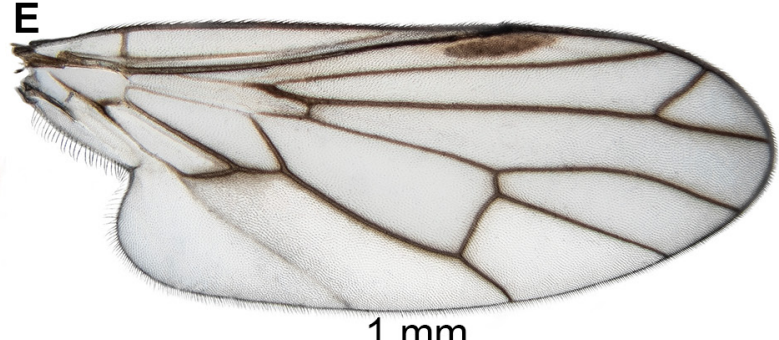

$1 \mathrm{~mm}$

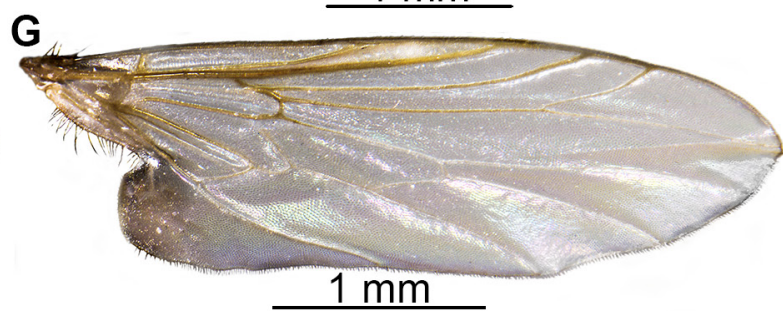

Fig. 9. Right wing. A. Ragas unica Walker, 1837, drawing with terminology on characters (left) and photo (right) (NHRS). B. Dipsomyia spinifera Bezzi, 1909 (MTD). C. Hydropeza longipennae (Miller, 1923) (dark colour is from underlying board to which the wing is glued) (NZAC 04021412). D. Zanclotus dioktes Wilder, 1982 (USNM). E. Iteaphila macquarti Zetterstedt, 1838 (NHRS). F. Anthepiscopus oedalinus (Zetterstedt, 1838) (NHRS-GULI000058764). G. Hormopeza obliterata Zetterstedt, 1838 (NHRS-000061621). 


\section{Material examined of Ragas unica}

Lectotype

SWEDEN • 1 q; UZIL 2629:1.

Paralectotype

SWEDEN • 1 \%; UZIL 2629:2.

\section{Other material}

SWEDEN • 1 ठ̊; Västerbotten, Vindelns kommun, Kulbäckslidens trail park; 2 Dec. 2003-16 Jun. 2004; Swedish Malaise Trap Project leg.; Malaise trap, dense, 25 years old mixed coniferous forest; DNA voucher AB7E, NHRS • 1 क; Småland, Högsby kommun, Hornsö kronopark, vicinity of Skärsgölorna, near end of Nya Kringlavägen; 30 Jun.-10 Jul. 2004; Swedish Malaise Trap Project leg.; Malaise trap, birch fen; DNA voucher AS9E, NHRS.

\section{Description}

Eyes bare; males holoptic (Fig. 6A). Scape bare; postpedicel tapering; stylus cylindrical (Fig. 6A). Epipharyngal blades (Fig. 6D) and ventroapical comb present. Postgena with stout spine-like setae (Fig. 6A). Prosternum separated from proepisternum forming an isolated sclerite; laterotergite bare. Stout spine-like setae on anterior face of fore coxa and on inner ventral margin of fore trochanter present (Fig. 6A); tubercle on fore coxa absent; male fore tarsal claws present. In wings, costal bristle absent; subcosta reaching costa; $\mathrm{R}_{4+5}$ divided (or branching) into $\mathrm{R}_{4}$ and $\mathrm{R}_{5}$; CuA straight (Fig. 9A). Females: tergite 10 undivided. Males: postgonites articulated to hypandrium; ventral surstylus position subapical, on inner margin of epandrium (Fig. 6G); apex of phallus membranous (Fig. 6F).

\section{Distribution}

Holarctic, with records from North America through Europe and Russia to East Asia (Sinclair \& Saigusa 2001).

Genus Dipsomyia Bezzi, 1909

Figs 2C, 7A, D, 9B

\section{Diagnosis}

Species in the genus Dipsomyia are distinguished from those in Ragas and Zanclotus by the lack of stout setae on postgena and the fore trochanter. The lack of pubescence on the eyes, the setose laterotergite and the isolated prosternum separates the species of Dipsomyia from Hydropeza.

\section{Type species}

Dipsomyia spinifera Bezzi, 1909.

\section{Material examined of Dipsomyia spinifera}

\section{Holotype}

CHILE • O; [Quillota]; [1000 m a.s.1.]; 22 Sep. 1902; W. Schnuse leg.; MTD.

\section{Description}

Eyes bare (Fig 7A); males dichoptic (Sinclair 1999). Scape with setae; postpedicel tapering; stylus tapering. Epipharyngal blades and ventroapical comb present. Postgena bare or with setae, not spine like (Fig. 7A). Prosternum separated from proepisternum forming an isolated sclerite (Fig. 7D); laterotergite with setae. Stout spine like setae on anterior face of fore coxa present; spine like setae on inner ventral 
margin of fore trochanter absent; tubercle on fore coxa absent (Fig. 7D); male fore tarsal claws present. In wings, costal bristle present; subcosta reaching costa; $\mathrm{R}_{4+5}$ branched; CuA straight (Fig. 9B). Females: tergite 10 divided medially. Males: postgonites as fused processes from hypandrium; ventral surstylus position apical; apex of phallus membranous (Sinclair 1999).

\section{Distribution}

The only known species in this genus is endemic to Chile.

Genus Hydropeza Sinclair, 1999

Figs 3, 7B, 7E-F, 9C

\section{Diagnosis}

The species in the genus Hydropeza resemble those of Dipsomyia by lacking the stout setae on the postgena, and the fore trochanter that is present in species in the genera Ragas and Zanclotus. Species in Hydropeza are distinguished from those in Dipsomyia by having pubescent eyes, a bare laterotergite, and a prosternum that is fused with the proepisternum and forming a precoxal bridge.

\section{Type species}

Trichopeza longipennae (Miller, 1923).

\section{Material examined of Trichopeza longipennae}

\section{Lectotype}

NEW ZEALAND • 1 क; Otira; 10 Jan. 1920; NZAC 04021412.

\section{Paralectotype}

NEW ZEALAND • 2 q ; ; same data as for lectotype; NZAC 04021441 , NZAC 04021437.

\section{Other material}

NEW ZEALAND • 1 ð̊; Mount Arthur, Flora Street; 3000 ft; 20 Nov. 1969; B.M. May leg.; on surface; $\mathrm{NZAC} \cdot 2$ 우; same data as for preceding; NZAC.

\section{Description}

Eyes pubescent (Fig. 7B); males dichoptic. Scape with setae; postpedicel tapering; stylus tapering. Epipharyngal blades present; ventroapical comb on labrum absent. Postgena bare or with setae (Fig. 7B), not spine like. Prosternum fused with proepisternum forming a precoxal bridge (Fig. 7E); laterotergite bare. Stout spine like setae on anterior face of fore coxa present; spine like setae on inner ventral margin of fore trochanter absent; tubercle on fore coxa absent (Fig. 7F); male fore tarsal claws present. In wings, costal bristle present; subcosta abruptly incomplete; $\mathrm{R}_{4+5}$ branched; CuA recurved (Fig. 9C). Females: tergite 10 undivided. Males: postgonites as fused processes from hypandrium; ventral surstylus position apical; apex of phallus membranous.

\section{Distribution}

This genus is known from Chile, west Australia and New Zealand (Sinclair 2016). 
Genus Zanclotus Wilder, 1982

Figs 4A, 7C, 7G, 9D

\title{
Diagnosis
}

The species in the genus Zanclotus are most similar to those in the genus Ragas, particularly by the presence of spine-like setae on postgena, and the inner margin of the fore trochanter. The species are distinguished from the species of Ragas by the pubescent eyes and recurved $\mathrm{CuA}$ in the wings. A unique character of species of Zanclotus is the presence of a tubercle on the coxa of each fore leg.

\section{Type species}

Zanclotus dioktes Wilder, 1982.

\section{Material examined of Zanclotus dioktes}

\section{Holotype}

USA - ${ }^{\text {; }}$; Washington, Mt. Rainer Nat. Park, Edith Cr. at Paradise Park; 1650 m a.s.1.; 11 Oct. 1979; D. Wilder leg.; USNM.

\author{
Allotype \\ USA $\bullet 1$; same data as for holotype; USNM.
}

\section{Description}

Eyes pubescent (Fig. 7C); males dichoptic. Scape with setae, postpedicel tapering; stylus tapering. Epipharyngal blades and ventroapical comb present. Postgena with stout spine like setae (Fig. 7C). Prosternum separated from proepisternum forming an isolated sclerite; laterotergite bare. Stout spine like setae on anterior face of fore coxa and on inner ventral margin of fore trochanter present; tubercle on fore coxa present (Fig. 7G); male fore tarsal claws present. In wings, costal bristle absent; subcosta reaching costa; $\mathrm{R}_{4+5}$ branched; CuA recurved (Fig. 9D). Female: tergite 10 absent. Male: postgonites articulated to hypandrium; ventral surstylus position apical; apex of phallus membranous.

\section{Distribution}

Only two species are known, both from Washington State, USA.

Subfamily Iteaphilinae Wahlberg \& Johanson, 2018

Figs 4B-C, 5, 9E-G

\section{Diagnosis}

The species in this subfamily are recognized by the broad and rectangular tergite 8 in the males. All species lack spine like setae on fore coxa, in contrast to species in the subfamily Ragadinae, and the labrum is straight, except for females in the genus Hormopeza.

\section{Type genus}

Iteaphila Zetterstedt, 1838.

\section{Description}

Postpedicel (Fig. 6B) at least three times as long as wide (except for Hormopeza). Labrum straight in males (Fig. 6E). Lacking anterior stout, spine like setae on the fore coxa, at most slender setae are present (Fig. 6C). Male: tergite 8 broad and rectangular in shape; ventral surstylus absent (Fig. 6H), except for the 'Iteaphila setosa-group'. 


\section{Included genera}

Iteaphila Zetterstedt, 1838.

Anthepiscopus Becker, 1891.

Hormopeza Zetterstedt, 1838.

Genus Iteaphila Zetterstedt, 1838

Figs 4B, 6B, 6E, 6H, 8C

\section{Diagnosis}

The synapomorphies of this genus and Anthepiscopus are the loss of epipharyngal blades and the tergite 10 fused with the cercus in females. Both males and females possess a straight labrum, in contrast to Hormopeza spp., where only males possess a straight labrum. Further similarities with species in Anthepiscopus are the setose scape, the loss of costal bristle and the recurved $\mathrm{CuA}$ in the wings (except for 'Iteaphila setosa-group' for the latter two characters). The species in the genus are distinguished from those of Anthepiscopus by having a branched $\mathrm{R}_{4+5}$.

\section{Type species}

Iteaphila macquarti Zetterstedt, 1838.

\section{Material examined of Iteaphila macquarti}

\section{Lectotype}

NORWAY• 1 §̊; "Werdalen, Naes"; [4 Jun.]; D. Boheman leg.; MZLU 3028:1.

\section{Other material}

SWEDEN • 1 đ̧; Lappland, Kiruna kommun, Abisko nationalpark, Nuolja; 26 Jun.-15 Jul. 2006; Swedish Malaise Trap Project leg.; Malaise trap, bare mountain; DNA voucher AD7E; NHRS • 23 우; same data as for preceding; NHRS.

\section{Description}

Eyes bare; males holoptic. Scape with setae; postpedicel tapering, at least 3 times as long as wide; stylus cylindrical (Fig. 6B). Labrum straight in both sexes (6E); epipharyngal blades and ventroapical comb absent. Postgena bare or with setae, not spine like (Fig. 6C). Prosternum separated from proepisternum and forming an isolated sclerite; laterotergite bare. Stout spine-like setae present on anterior face of fore coxa and inner ventral margin of fore trochanter absent (Fig. 6C); tubercle lacking on fore coxa; male fore tarsal claws present. Costal bristle absent; subcosta reaching costa; $\mathrm{R}_{4+5}$ branched; $\mathrm{CuA}$ recurved (Fig. 9E). Females: tergite 10 fused to cercus (Fig. 8C). Males: postgonites form fused processes from hypandrium; the apex of the phallus is simple (Fig. $6 \mathrm{H}$ ).

\section{Distribution}

The genus Iteaphila is the most widely spread group within the Ragadidae, with representatives in the Nearctic, Palaearctic and Oriental regions (Shamshev \& Sinclair 2009; Sinclair \& Shamshev 2012).

\section{Comments}

Sinclair \& Saigusa (2001) transferred Ragas setosa (Bezzi 1924) to the genus Iteaphila based on the presence of a straight labrum, the absence of spine like setae on fore coxa and postgena, the palpus projection and the shape of the male terminalia. Shamshev \& Sinclair (2009) assigned this species together with several other from the southern Europe, the northern Africa and the Middle East to the 'Iteaphila setosa-group'. This group, however, possesses species with numerous peculiar characters 
such as both ventral and dorsal surstyli, costal bristle, antennal shape and modification in male hind femur, and its affinity to other species in Iteaphila is unclear. For the analysis herein, the characters present in the type species were used and the above listed characters treated as uniquely or possibly secondarily derived in the group. Further examination of morphological characters such as mouthparts, as well as DNA data is needed to clarify the phylogenetic position of this group.

Genus Anthepiscopus Becker, 1891

Figs $4 \mathrm{C}, 9 \mathrm{~F}$

\section{Diagnosis}

The species of this genus share synapomorphies and similarities with the species of the genus Iteaphila, which also separate these two genera from Hormopeza. These characteristics include the lack of epipharyngal blades, the straight labrum in both sexes, the setose scape, the loss of costal bristle in the wings, the recurved $\mathrm{CuA}$, and the tergite 10 fused to the cercus in females. The species of this genus are distinguished from those of Iteaphila by the presence of an unbranched $\mathrm{R}_{4+5}$.

\section{Type species}

Anthepiscopus ribesii Becker, 1891.

\section{Material examined of Anthepiscopus ribesii}

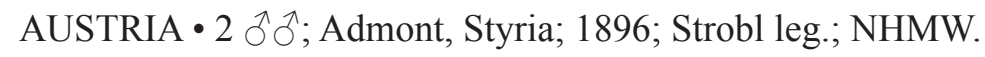

Material examined of Anthepiscopus oedalinus (Zetterstedt, 1838)

SWEDEN • 1 क; [Lapponia inferior, Lappland]; [D. Boheman leg.]; NHRS-GULI000058763 • 1 đ;; same data as for preceding; NHRS-GULI000058764.

\section{Description}

Eyes bare; males holoptic. Scape with setae; postpedicel tapering, at least three times as long as wide; stylus cylindrical. Labrum straight in both sexes; epipharyngal blades and ventroapical comb absent. Postgena bare or with setae, not spine like. Prosternum separated from proepisternum forming an isolated sclerite; laterotergite bare. Stout spine like setae on anterior face of fore coxa and on inner ventral margin of fore trochanter absent; tubercle on fore coxa absent; male fore tarsal claws present. In wings, costal bristle absent; subcosta reaching costa; $\mathrm{R}_{4+5}$ unbranched; CuA recurved (Fig. 9F). Female: tergite 10 fused to cercus. Male: postgonites as fused processes from hypandrium; apex of phallus simple.

\section{Distribution}

This genus is represented in the Nearctic and west Palearctic. In addition, one species is recorded from Australia.

Genus Hormopeza Zetterstedt, 1838

Figs $5,8 \mathrm{~A}-\mathrm{B}, 8 \mathrm{D}$

\section{Diagnosis}

The species of the genus Hormopeza are separated from the species of Iteaphila and Anthepiscopus by the presence of epipharyngal blades and costal bristle, the scape is bare and CuA straight. Males lack claws on the fore legs, and females have a recurved labrum a tergite 10 separate from to cercus. 


\section{Type species}

Hormopeza obliterata Zetterstedt, 1838.

\section{Material examined of Hormopeza obliterata}

Holotype

FINLAND • ^`; Turtola; [25 Aug. 1821]; MZLU 5863:1.

\section{Other material}

SWEDEN • 1 §; Dalarna, Falun, Svartnäs, Lill-Sixen, burnt 1999; 15-17 Jun. 1999; Malaise trap; NHRS-000061670 • 1 \% ; same data as for preceding; NHRS-000061621.

\section{Description}

Eyes bare; male eyes holoptic. Scape bare; postpedicel ovate and broad, at most two and a half times as long as broad; stylus cylindrical (Fig. 8A). Labrum recurved in females only; epipharyngal blades and ventroapical comb present (Fig. 8A). Postgena bare or with setae, not spine like. Prosternum separated from proepisternum forming an isolated sclerite; laterotergite bare. Stout spine like setae on anterior face of fore coxa and inner ventral margin of fore trochanter absent; tubercle on fore coxa absent; male fore tarsal claws absent (Fig. 8B). Costal bristle present; subcosta reaching costa; $\mathrm{R}_{4+5}$ branched; $\mathrm{CuA}$ straight. Female: tergite 10 undivided (Fig. 8D). Male: postgonites form fused processes from hypandrium; apex of phallus membranous.

\section{Distribution}

Hormopeza spp. are known from the Nearctic, Palaearctic, Oriental and Neotropical regions (Daugeron 1999).

\section{Discussion}

When Chvála described the subfamily Oreogetoninae (Chvála 1976), he expressed a probable close relationship between the genera Anthepiscopus and Iteaphila and the genera Hormopeza and Ragas. However, more recent authors considered the groups of Iteaphila and Ragas only as distant relatives with the 'Iteaphila-group' as incertae sedis within the Empidoidea, and the 'Ragas-group' as incertae sedis within the Empididae (Sinclair \& Cumming 2006), or later as a subfamily within the Empididae (Sinclair 2016). In Wahlberg \& Johanson (2018), the close relationship between Anthepiscopus, Iteaphila and Ragas was re-established, and the family Ragadidae was established based on the molecular distances separating this group and the Empididae. The present study further explores this concept, and the analysis of morphological data indicates a distinct clade including Iteaphila, Anthepiscopus and Hormopeza separate from the remaining Ragadidae. The synapomorphy of this group including Hormopeza in the 'Ragas-group', according to Sinclair (1999) and Sinclair \& Cumming (2006), is a membranous distiphallus. However, this character may vary in different degree of sclerotization and form, even within empidoid genera (e.g., in Hesperemis Melander, 1906, see Cumming et al. 2013). The recurved labrum is found to be a homoplastic character in the phylogenetic analysis in the present study. The genus Hormopeza is therefore transferred from this subfamily. The diagnosis and description of the Iteaphilinae and the Ragadinae are updated to reflect the results herein, based on labrum shape, chaetotaxy of fore coxa, and characters in male genitalia. The monophyly of the genus Iteaphila in relation to Anthepiscopus is dubious (Sinclair \& Shamshev 2012), which was also indicated in Walberg \& Johanson (2018). Further molecular studies including a broader taxon sampling are required to resolve this relationship, as well as the monophyly in regard to the 'Iteaphila setosagroup'. The morphological similarities reviewed herein between Ragas and Zanclotus is coherent with the results in Sinclair (1999). The spine like setae on fore coxa and postgena, and the fore coxal tubercle in Zanclotus, are hypothesized to be morphological adaptations to catch and handle prey. The presence 
of epipharyngal blades strengthens the notion of a predatory lifestyle as these may be used in cutting prey tissue (Bletchly 1954; McAlpine 1981). Species in the genus Hormopeza lack the spine-like setae on for coxa present in species of the Ragadinae, and species in Anthepiscopus and Iteaphila also lack epipharyngal blades. Iteaphila has been observed feeding on flowers (Shamshev \& Sinclair 2009), especially in early spring and may be an early pollinator. Many of the species of the Ragadidae are rarely collected, and there have been few observations of feeding and mating behaviour. A few genera remain unplaced, e.g., Oreogeton within the Empidoidea. Further studies, preferably combinations of molecular and morphological methods, are warranted to properly assign Oreogeton and the other unplaced genera to formal taxonomic groups. Steps towards accessible and thorough classification, not only in this group, but also within other groups within the Empidoidea, together with up-to-date determination keys may, hopefully, lead to more attention to these flies and their roles in ecological systems.

\section{Acknowledgements}

The following people are thanked for assistance in loans of material used in this study: Rune Bygebjerg (MZLU), Dr. Torsten Dikow (USNM), Dr. Allen L. Norrbom (USNM), Dr. Michael Ohl (MTD), and Dr. Darren Ward (NZAC). Dr. Bradley Sinclair (Canadian National Collection of Insects and Canadian Food Inspection Agency) have provided interesting feedback and insights in empidoid systematics and taxonomy.

\section{References}

Bletchly J.D. 1954. The mouth-parts of the dance fly, Empis livida L. (Diptera, Empididae). Proceedings of the Zoological Society of London 124: 317-334. https://doi.org/10.1111/j.1469-7998.1954.tb07785.x

Chvála M. 1976. Swarming, mating and feeding habits in Empididae (Diptera), and their significance in evolution of the family. Acta Entomologica Bohemoslovaca 73: 353-366.

Chvála M. 1983. The Empidoidea (Diptera) of Fennoscandia and Denmark. 2: General part. The families Hybotidae, Atelestidae and Microphoridae. Fauna Entomologica Scandinavica. Scandinavian Science Press, Klampenborg.

Cumming J.M. \& Wood D.M. 2009. Adult morphology and terminology. In: Brown B.V., Borkent A., Cumming J.M., Wood D.M. \& Zumbado M. (eds) Manual of Central American Diptera 1: 9-50. National Research Council Research Press, Ottawa.

Cumming J.M. \& Wood D.M. 2017. Adult morphology and terminology. In: Kirk-Spriggs A. \& Sinclair B.J. (eds) Manual of Afrotropical Diptera 1: 112. South African National Biodiversity Institute, Cape Town.

Cumming J.M., Brooks S.E. \& Saigusa T. 2013. Revision of the Hesperempis genus group (Diptera: Empidoidea:Empididae). The Canadian Entomologist 146: 170-210.https://doi.org/10.4039/tce.2013.66

Daugeron C. 1999. First neotropical record of the genus Hormopeza Zetterstedt, 1838 (Diptera, Empididae). Zoosystema 21: 121-126.

Evenhuis N.L. 2019. The Insect and Spider Collections of the World Website. Available from http://hbs.bishopmuseum.org/codens/ [accessed 10 Jan. 2019].

McAlpine J.F. 1981. Morphology and terminology - adults. In: McAlpine J.F., Peterson B.V., Shewell G.E., Teskey H.J., Vockeroth J.R. \& Wood D.M. (eds) Manual of Nearctic Diptera: 9-63. Agriculture Canada, Ottawa.

Maddison D.R. \& Maddison W.P. 2001. MacClade 4: Analysis of Phylogeny and Character Evolution. Version 4.03. Sinauer Associates, Sunderland. 
Sinclair B.J. \& Saigusa T. 2001. Revision of the world species of Ragas Walker (Diptera: Empidoidea). Entomological Science 4: 507-522.

Shamshev I.V. \& Sinclair B.J. 2009. Revision of the Iteaphila setosa group (Diptera: Empididae). European Journal of Entomology 106: 441-450. https://doi.org/10.14411/eje.2009.055

Sinclair B.J. 1995. Generic revision of the Clinocerinae (Empididae), and description and phylogenetic relationships of the Trichopezinae, new status (Diptera: Empidoidea). The Canadian Entomologist 127: 665-752. https://doi.org/10.4039/Ent127665-5

Sinclair B.J. 1999. Review of the genera Dipsomyia Bezzi, Zanclotus Wilder, and an allied new Gondwanan genus (Diptera: Empidoidea, Ragas-group). Entomological Science 2: 131-145.

Sinclair B.J. 2016. Revision of the Australian species of Hydropeza Sinclair (Diptera: Empididae: Ragadinae subfam. nov.). Records of the Australian Museum 68: 1-22. https://doi.org/10.3853/j.2201-4349.68.2016.1657

Sinclair B.J. \& Cumming J.M. 2006. The morphology, higher-level phylogeny and classification of the Empidoidea (Diptera). Zootaxa 1180: 1-170. https://doi.org/10.11646/zootaxa.1180.1.1

Sinclair B.J. \& Saigusa T. 2001. Revision of the world species of Ragas Walker (Diptera: Empidoidea). Entomological Science 4: 507-522.

Sinclair B.J. \& Shamshev I.V. 2012. World revision of Iteaphila macquarti group (Diptera: Empididae). Zootaxa 3561: 1-61.

Stuckenberg B.R. 1999. Antennal evolution in the Brachycera (Diptera), with a reassessment of terminology relating to the flagellum. Studia Dipterologica 6: 33-48.

Swofford D.L. 2003. PAUP*. Phylogenetic Analysis Using Parsimony (*and Other Methods). Version 4. Sinauer Associates, Sunderland.

Wahlberg E. \& Johanson K.A. 2018. Molecular phylogenetics reveals novel relationships within Empidoidea (Diptera). Systematic Entomology 43: 619-636. https://doi.org/10.1111/syen.12297

Manuscript received: 18 March 2019

Manuscript accepted: 4 April 2019

Published on: 29 April 2019

Topic editor: Gavin Broad

Desk editor: Alejandro Quintanar

Printed versions of all papers are also deposited in the libraries of the institutes that are members of the EJT consortium: Muséum national d'Histoire naturelle, Paris, France; Meise Botanic Garden, Belgium; Royal Museum for Central Africa, Tervuren, Belgium; Royal Belgian Institute of Natural Sciences, Brussels, Belgium; Natural History Museum of Denmark, Copenhagen, Denmark; Naturalis Biodiversity Center, Leiden, the Netherlands; Museo Nacional de Ciencias Naturales-CSIC, Madrid, Spain; Real Jardín Botánico de Madrid CSIC, Madrid, Spain; Zoological Research Museum Alexander Koenig, Bonn, Germany. 